\title{
Reproduction of Amphiporus lactifloreus (Hoplonemertini) on tidal flats: implications for studies on the population biology of nemertines
}

\author{
Martin Thiel ${ }^{1,2,{ }^{*}} \&$ Thorsten Dernedde ${ }^{1,3}$ \\ ${ }^{1}$ Biologische Anstalt Helgoland, Wattenmeerstation Sylt; D-25992 List, Germany \\ ${ }^{2}$ Universität Kiel, Zoologisches Institut, Arbeitsgruppe Marine Ökologie und Systematik; \\ Olshausenstr. 40-60, D-24118 Kiel, Germany \\ ${ }^{3}$ Universität Kiel, Institut für Haustierkunde; Olshausenstr. 40-60, D-24118 Kiel, \\ Germany
}

\begin{abstract}
The reproductive period and life-history parameters were investigated for the hoplonemertine Amphiporus lactifloreus found on the tidal flats of the island of Sylt in the northern Wadden Sea. Every six weeks 20 individuals were collected and then histologically examined to determine the development stage of their reproductive organs. A. lactifloreus reproduces in the late autumn, its peak reproduction being in the second half of November. Individuals from all size classes $>20 \mathrm{~mm}$ body length produced gametes. Individuals of the cohorts that reproduced in the late autumn of 1992 persisted and grew until July 1993, indicating that A. lactifloreus is an iteroparous species. The length of relaxed individuals was significantly correlated with their length under anaesthetized conditions, but the regression changed significantly after the reproductive period. Length under 'relaxed' conditions was significantly correlated with weight (wet weight, dry weight, and ash-free dry weight); these relationships did not vary significantly before or after the reproductive period. Our results show that important life-history data of intertidal nemertines can be obtained without time-consuming histological studies. On the basis of these findings, recommendations for future studies on the population biology of intertidal nemertines are given. Regular length measurements of nemertines under 'relaxed' conditions are proposed as a useful tool for tracking the growth and survival of annual cohorts of intertidal nemertines.
\end{abstract}

\section{INTRODUCTION}

Nemertines are important endobenthic predators in estuarine ecosystems (Roe, 1970, 1976, 1993; Reise, 1985; McDermott, 1984, 1993; Ambrose, 1991). They may have a significant predation effect on their prey populations (Roe, 1976; Nordhausen, 1988; Rowell \& Woo, 1990), or they may provoke prey movements within tidal flats (Thiel \& Reise, 1993). To understand the role of nemertines in benthic assemblages, a basic knowledge of their population biology is crucial. However, there are only scattered records of the occurrence of intertidal nemertines, and apart from the studies by Roe $(1970,1976,1993)$ detailed studies on the population biology of intertidal nemertines do

\footnotetext{
- Present address: Darling Marine Center, University of Maine; Walpole, ME 04573, USA
} 


\begin{tabular}{|c|c|c|c|c|c|c|c|c|c|c|c|c|c|}
\hline & Jan. & Fab. & Mar & Apr. & May & June & July & Aug. & Sept. & Oct. & Nov. & Dec. & \\
\hline Gullmar Fjord, Sweden & & & & & & & & & & & & & Franzen (1956) \\
\hline North Sea \& British tsies & & & & & & & & & & & & & Bürger (1907) \\
\hline British isles & & & & & & & & & & & & & Gibson (1972) \\
\hline French Atlantic Coast & & & & & & & & & & & & & Bürger (1907) \\
\hline Britanny, French Atlantic Coast & & & & & & & & & & & & & Bierne \& Rue (1979) \\
\hline Mediterranean & & & & & & & & & & & & & Bürger (1907) \\
\hline
\end{tabular}

Fig. 1. Reproductive periods of Amphiporus lactifloreus in different regions of the northern hemisphere

not exist. Our present knowledge of interannual variations in nemertine abundance is very limited. When looking for information on recruitment processes and the factors that influence them, one must fall back on reports of an observational nature (e.g. Coe, 1943; Riser, 1974). In the case of most nemertine species it is unknown whether they reproduce more than once during their lifetime. Apart from a few historical reports on individuals surviving for several years in the laboratory (McIntosh, 1873/74), nothing is known about their life-span (Gibson, 1972). This elucidates the need to foster our knowledge of basic life-history information of nemertines.

As a step in this direction, we investigated the reproductive biology of Amphiporus lactifloreus. This hoplonemertine is a common endobenthic predator in many coastal areas of Europe (Gibson, 1972, 1982), and it can frequently be found on the tidal flats of the Nord-Sylter Wattenmeer (Reise, 1985; Thiel \& Reise, 1993; Albrecht \& Reise, 1994). In order to reveal basic information on the life-history of this species and to provide methods to improve studies of the population biology of this and other intertidal nemertine species, we addressed the following questions:

When is the reproductive period of A. lactifloreus? - The available data on the reproductive period of this nemertine species in Europe vary considerably (Fig. 1).

Do all individuals of the population participate in a reproduction event? - For population studies it is of prime importance to know when a species achieves maturity.

Is A. lactifloreus semelparous or iteroparous? - Coe (1943) mentions that large nemertine species probably reproduce in several successive years (iteroparous), whereas smaller species probably die after their first reproduction. Riser (1974) recorded that individuals of Lineus viridis die as a consequence of spawning, and that after the reproductive period only very small individuals can be found on tidal flats.

Furthermore, in order to facilitate future studies on the population biology of $A$. lactifloreus (and other nemertines), we examined whether length is a measure potentially indicative of different age classes.

\section{MATERIAL AND METHODS}

The study was conducted on the tidal flats of the Nord-Sylter Wattenmeer. The tidal range is about $1.8 \mathrm{~m}$ (Reise, 1985). In this area, Amphiporus lactifloreus can reach densities of up to 250 individuals $/ \mathrm{m}^{2}$ (Thiel \& Reise, 1993). Mussel clumps, which are an important micro-habitat of this nemertine, are very abundant in the study area (Reise et al., 1989; Albrecht, 1991). 


\section{Examination of the reproductive stage of Amphiporus lactifloreus}

We collected A. lactifloreus from the tidal flats of the island of Sylt in the northern Wadden Sea between August 1992 and July 1993 every 6-8 weeks. On each sampling date we collected 20-24 individuals which were separated from mussel clumps in the field. We measured their length by allowing them to crawl along a ruler (described below in 'Biometrics of $A$. lactifloreus'). Nemertines were grouped into 7 different length classes according to the measurements under 'relaxed' conditions $(\leq 20 \mathrm{~mm} ; 21-30 \mathrm{~mm}$; 31-40 mm; 41-50 mm; 51-60 mm; 61-70 $\mathrm{mm}_{;}>70 \mathrm{~mm}$ ). Before fixation, the nemertines were anaesthetized with $7.5 \% \mathrm{MgCl}_{2}$-solution. Specimens were fixed in Bouin's fluid for $24 \mathrm{~h}$ and then transferred to $70 \%$ alcohol. Animals were embedded in $54^{\circ} \mathrm{C}$ paraffin wax for sectioning.

In order to examine the reproductive stage of the gonads, we prepared sections $(6-8 \mu \mathrm{m})$ from the middle part of every animal's body. The sections were stained using the Mallory-trichrome-method. We examined 50 sections of each individual under the microscope, determined its sex when possible, and classified the developmental stage of the gonads in every section according to the description presented in Table 1 . The latest stage of development that was found to be in majority after 50 sections of an individual were examined was used to classify its reproductive stage.

\section{Biometrics of Amphiporus lactifloreus}

In order to examine the general biometrics of Amphiporus lactifloreus and to test whether relationships between different, easily measurable parameters remained consistent, we collected nemertines in the autumn of 1991 (October) and in the spring of 1992 (March). We determined their natural length by allowing them to crawl along a ruler and reading the length when they were fully relaxed (= 'relaxed' nemertines; see also Gibson \& Young, 1976). As it proved to be a time-consuming task to get the nemertines to crawl along the ruler and to be more or less relaxed, we anaesthetized the nemertines in a $7.5 \%$ $\mathrm{MgCl}_{2}$-solution. After anaesthetizing the nemertines for about 10 minutes in the $\mathrm{MgCl}_{2}$ solution we again measured their length (= 'anaesthetized' nemertines) to establish a

Table 1. Classification of the reproductive stages of the hoplonemertine Amphiporus lactifloreus as recognizable in histological sections (6-8 $\mu \mathrm{m}$ thick)

\begin{tabular}{|c|c|c|}
\hline Stage & Term & Short description \\
\hline 0 & undeveloped & No gonads visible in the section \\
\hline 1 & resting & $\begin{array}{l}\text { Gonads visible but still adhering close to the body wall; oocytes and } \\
\text { spermatogonia visible }\end{array}$ \\
\hline 2 & maturing & $\begin{array}{l}\text { Gonads visibly protruding into the body lumen; oocytes increasing in } \\
\text { size, spermatocytes increasing in number }\end{array}$ \\
\hline 3 & mature & $\begin{array}{l}\text { Gonads filling most of the body lumen; oocytes and sperm densely } \\
\text { packed in the gonads, gonopores opening }\end{array}$ \\
\hline 4 & post-reproductive & $\begin{array}{l}\text { Gonads empty, only very few gametes remaining in the gonad lumen; } \\
\text { gonopores still opened }\end{array}$ \\
\hline
\end{tabular}



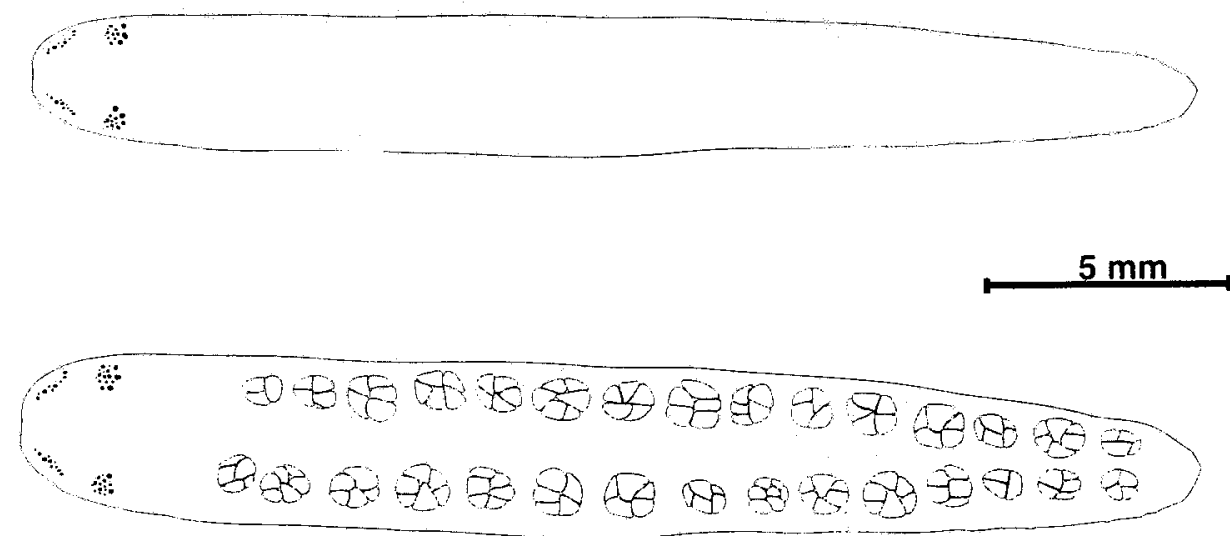

Fig. 2. Mature female (bottom) and male (top) individuals of Amphiporus lactifloreus. During the reproductive period, the ovaries with the eggs and the testes are easily recognizable in the field with the naked eye or with the aid of a hand lens

relationship between living and anaesthetized individuals. We then determined the wet weight, dry weight (after drying them for 3 days at $80^{\circ} \mathrm{C}$ ), ash weight (muffle furnace for 4 hours at $\left.510^{\circ} \mathrm{C}\right)$, and ash-free-dry-weight $(\mathrm{afdw}=\mathrm{dry}$ weight - ash weight).

\section{RESULTS}

\section{Reproductive stages and reproductive period of Amphiporus lactifloreus}

Amphiporus lactifloreus is dioecious. Females and males can be distinguished in the field only during the reproductive period. The reproductive products of mature individuals can be seen through the body wall. Mature eggs have a greenish-white appearance, and the observer in the field can easily recognize between 4 to 10 mature eggs in one ovary (Fig. 2). Male gonads containing sperm appear white. The mature male gonads are heavily folded, and in the field the borders between individual testes cannot be distinguished. Outside the reproductive period, males and females can only be distinguished by histological examination.

Animals collected between April and July sometimes had a bright orange or dark grey coloration, but the histological examination of these individuals showed that they did not contain mature eggs or sperm. During the rest of the year the animals appeared greyish-white.

In the histological sections, the gonads of nemertines that were in reproductive stage 1 (Table 1) were pressed close to the body wall. The intestinal lumen and the intestinal tissues occupied most of the body volume (Figs $3 a, 4 a)$.

Gonads of females in stage 1 contained previtellogenic oocytes (Fig. 3b). The nucleus appears translucent, and chromosomes are visible (Fig. 3b). Up to 15 of these previtellogenic oocytes can be found in one section of an ovary. Gonopores can be recognized in the sections, but their opening to the outside is very narrow. During the vitellogenic phase, the oocytes increase in size, the nucleus is no longer translucent in sections, and 



Fig. 3. Cross sections of female Amphiporus lactifloreus. a: overview; b: ovary in stage 1; c: ovary in stage 2; d: ovary with mature eggs. G gonads; g gonopores; I intestine; L lateral nerve cord; M longitudinal muscles; $R$ rhynchocoel. Scale bar $=0.1 \mathrm{~mm}$ in $\mathrm{a}-\mathrm{d}$

the ovaries protrude into the body (stage 2 - Fig. 3c). After maturation, ovaries containing oocytes almost completely occupy the body volume (stage 3 - Fig. 3d). Up to 5 mature oocytes can be seen in one section of an ovary. Mature oocytes are covered by a thin, hard layer, which is difficult to section and often causes artifacts in the sections (Fig. 3d).

Gonads of males in stage 1 contain spermatogonia (Fig. 4a). During spermatogenesis the number of spermatocytes rapidly increases, and subsequently the gonads extend into 

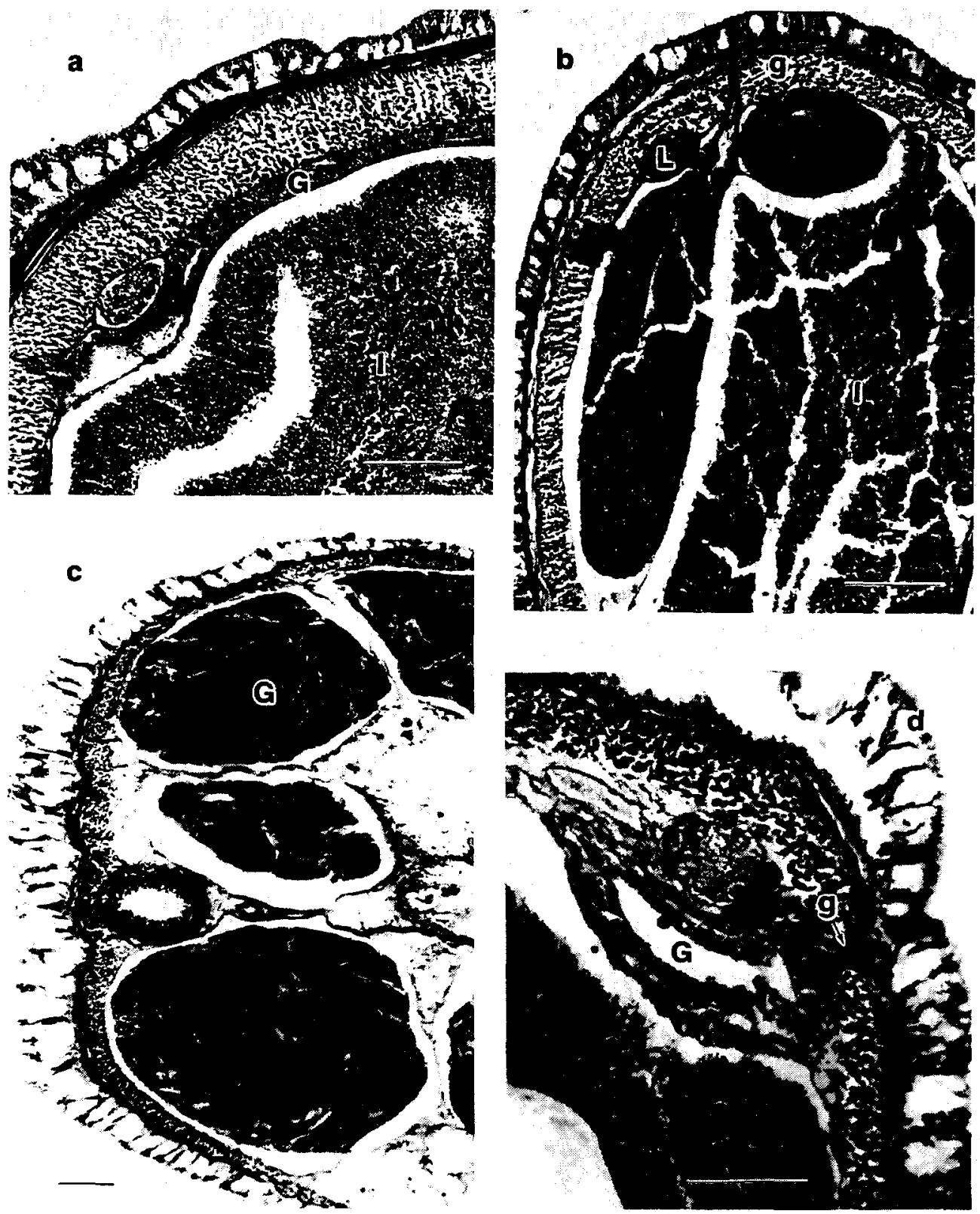

Fig. 4. Cross sections of male Amphiporus lactifloreus. a: testes in stage 1 (resting); b: testes in stage 2 ; c: testes with mature sperm - stage 3; d: empty testes immediately after the reproductive period stage 4. G gonads; $g$ gonopores; I intestine; $L$ lateral nerve cord. Scale bar $=0.1 \mathrm{~mm}$ in $a-d$ 


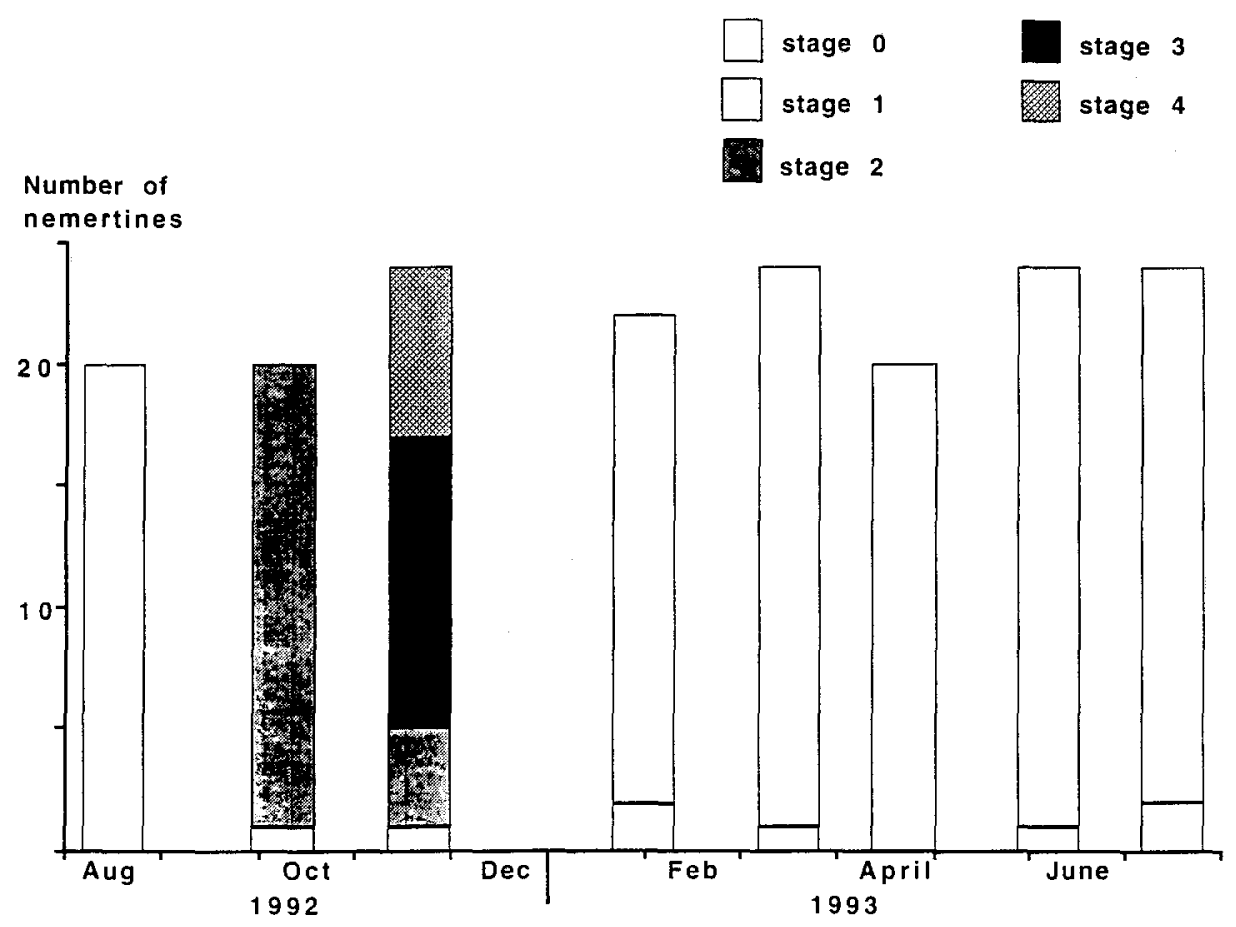

Fig. 5. Numbers of Amphiporus lactifloreus from the Nord-Sylter Wattenmeer in the respective reproductive stages during the 8 sampling periods. Stage 0 - undeveloped; stage 1 - resting; stage 2 - maturing; stage 3 - mature; stage 4 -post-reproductive. For further explanation see Table 1

the body cavity (stage 2 - Fig. 4 b). When spermiogenesis is completed (stage 3 ), the gonads occupy most of the body volume (Fig. 4c). After the reproductive period, empty gonads are visible in the sections and the gonopores, both in male and female individuals, are still open (stage 4 - Fig. 4d). Outside the reproductive period the columnar cells of the intestine are filled with many fat droplets (Figs 3b, 4a). During the reproductive period these columnar cells may be completely empty (Figs 3c, 4c).

Amphiporus lactifloreus has a clearly confined reproductive period in the NordSylter Wattenmeer (Fig. 5). Maturation of the gonads does not begin until August. In October 1992 almost all of the nemertines that were collected were in stage 2, and the ovaries and testes were maturing (Fig. 5). At the end of November (27th November 1992) more than half of the nemertines that were collected contained fully mature gametes, and 7 of 24 nemertines had already released their reproductive products. By the end of January (31st January 1993), all of the nemertines had spawned, and the gonads were again in stage 1.

\section{Biometrics of Amphiporus lactifloreus}

Nemertines were found in all length classes. Both sexes were represented in all length classes more or less equally (Fig. 6), except in the class $\leq 20 \mathrm{~mm}$, in which only 


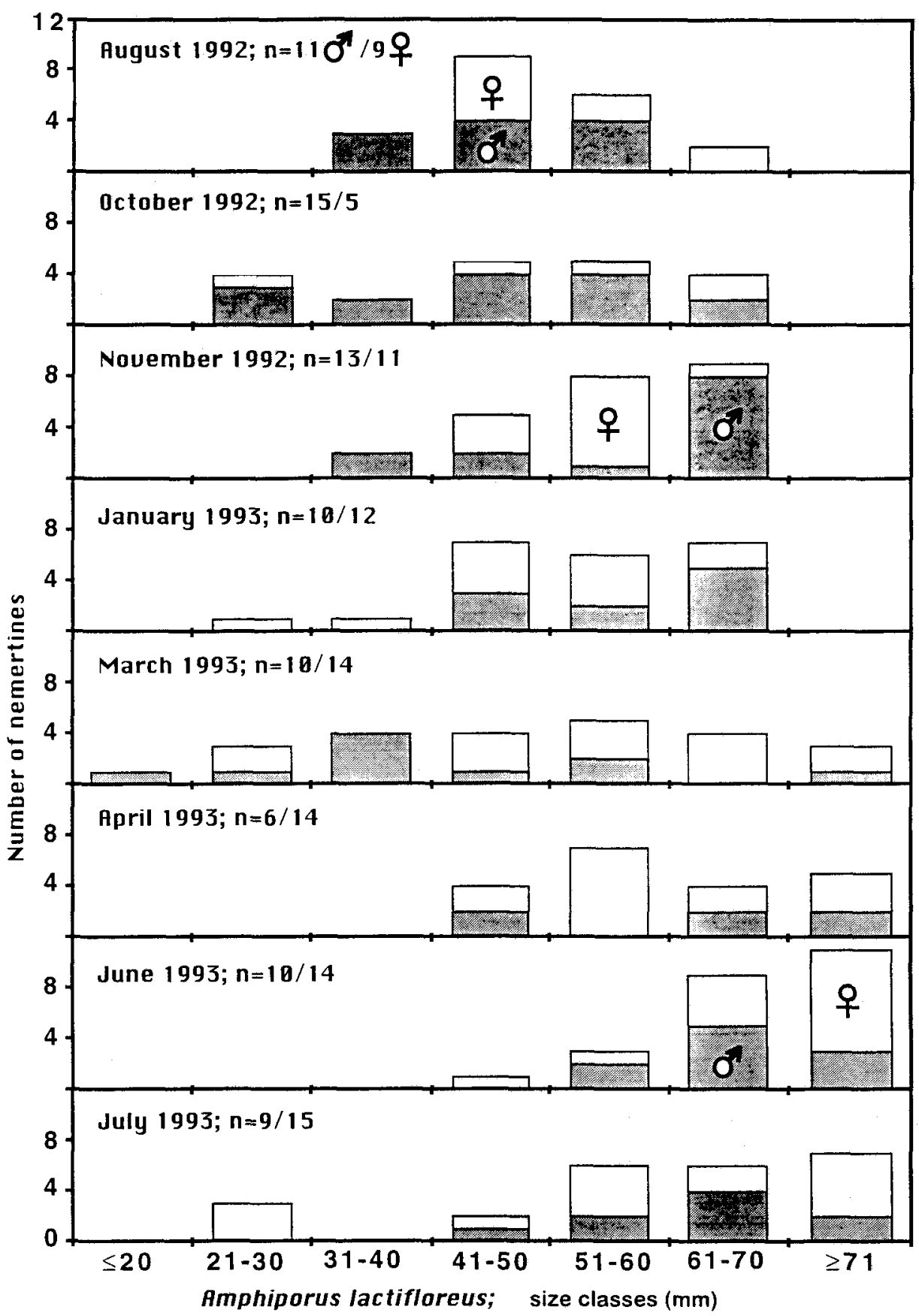

Fig. 6. Numbers of Amphiporus lactifloreus in each of the 7 size classes during the 8 sampling periods 

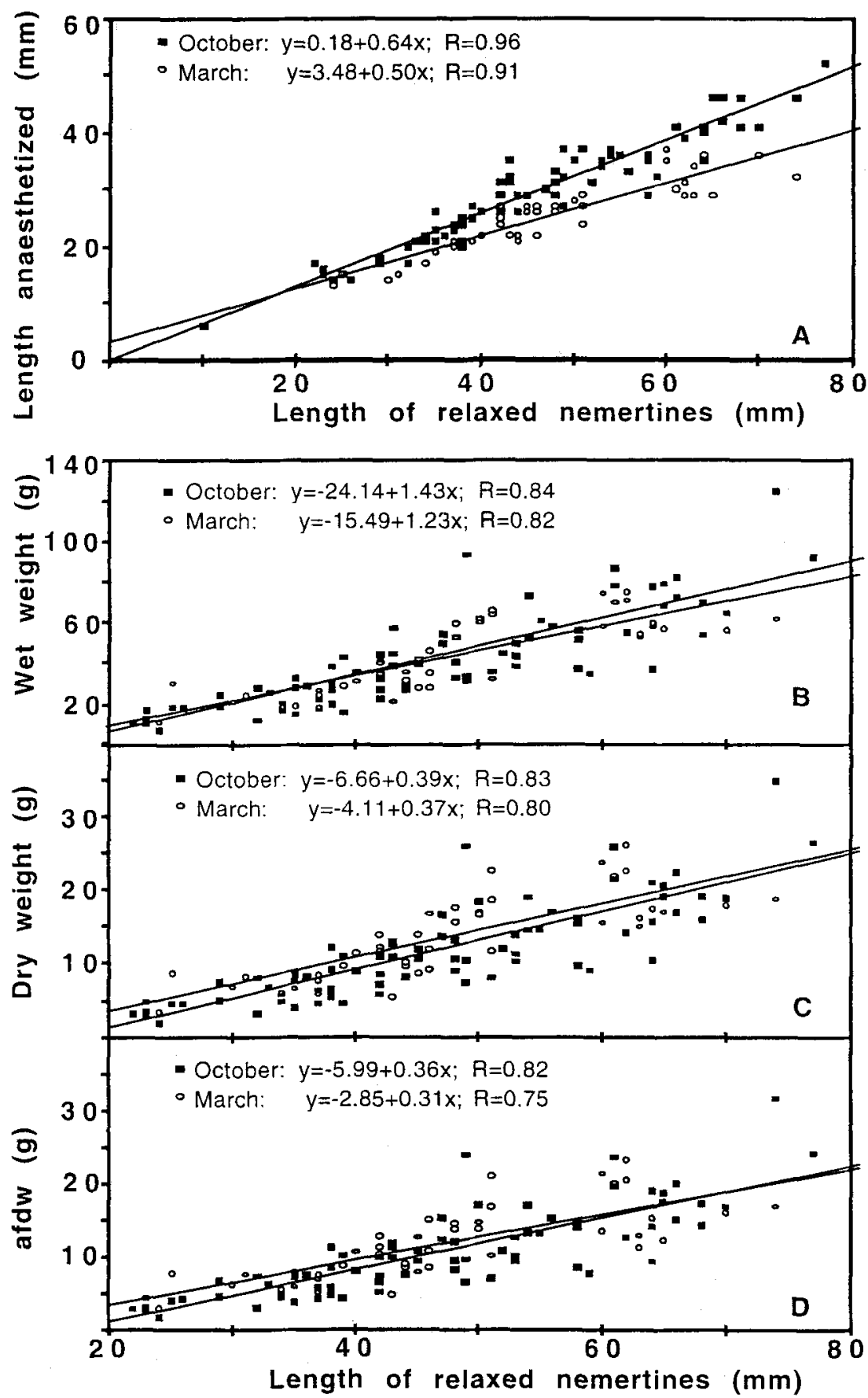

Fig. 7. Biometric relationship for Amphiporus lactifloreus in October 1991 ( $\mathrm{n}=78$ individuals) and March 1992 ( $n=40$ individuals). A: Linear regression of the length of anaesthetized individuals and the length of 'relaxed' individuals. B: Linear regression of wet weight and 'relaxed' length of different sizes of $A$. lactifloreus. C: Linear regression of dry weight and 'relaxed' length. D: Linear regression of ash-free dry weight and 'relaxed' length. Linear regressions between 'relaxed' length and weight data were only calculated for nemertines longer than the $20 \mathrm{~mm}$ 'relaxed' length (October: $n=77$ and March: $n=40$ ) 
one male was found. Male Amphiporus lactifloreus were in the majority before the reproductive period, whereas females dominated after the reproductive period (Fig. 6).

In January 1993, the numbers in the different length classes were almost the same as in November 1992. Thus it can be concluded that the majority of nemertines survived the reproductive period. Between August 1992 and January 1993, the distribution of nemertines in different length classes indicates a cohort with a modal size between 40 and $60 \mathrm{~mm}$ (Fig. 6). Beginning in March 1993, this cohort seemed to grow further, and in July 1993 most of the nemertines were longer than $60 \mathrm{~mm}$.

Both in November 1991 and March 1992, there was a strong correlation between the length of the nemertines measured when they were crawling along the ruler under 'relaxed' conditions and their length measured after being anaesthetized (Fig. 7a). A significant relationship existed between the relaxed length and the weight-data ( $w w, d w$ and afdw) of $A$. lactifloreus (Fig. $7 b, c, d$ ). No significant differences for any of the examined 'relaxed' length-weight relationships were found between the two sampling dates of October 1991 and March 1992 (t-test; p >0.05). However, the relationship between the length of 'relaxed' and anaesthetized nemertines changed significantly after the reproductive period ( $t$-test $; p<0.02$ ). The relationship between anaesthetized length and wet weight also changed significantly from October 1991 to March 1992 (t-test; $p<0.001$ ), whereas the other length-weight relationships ( $d w$, afdw) under anaesthetized conditions did not change in this time period $(p>0.05)$.

\section{DISCUSSION}

\section{Reproductive period of Amphiporus lactifloreus}

The hoplonemertine Amphiporus lactifloreus in the Wadden Sea reproduces during the late autumn. This is in clear contrast to most other reports of the reproductive period of this species (McIntosh, 1873-74; Bürger, 1897-1907; Franzen, 1956, 1983; Gibson, 1972). Bierne \& Rué (1979), who also examined histological sections, found a reproductive period in A. lactifloreus on the French Channel coast that is similar to that observed by us in the Wadden Sea. In April and June of 1993 we found individuals that matched the colour description given by Gibson (1972) for A. lactifloreus during their presumptive reproductive period, but none of our individuals revealed maturing or mature gonads during the histological examination (Fig 5). Individuals collected in November 1992 contained mature gonads. They could clearly be recognized as mature individuals in the field with the naked eye or with the aid of a hand lens. Interestingly, in none of the abovementioned reports is a description of mature individuals given that matches our observations. This leads us to suspect that in most cases the reported reproductive period of $A$. lactifloreus was not accurately identified. Mature individuals can easily be recognized in the field, providing an easy tool for re-examining the reproductive period of A. lactifloreus along the European coasts.

Most other nemertines from temperate regions of the northern hemisphere, for which reproductive data are available, reproduce during the spring and summer months (Fig. 8). The majority of nemertines are benthic predators, so it can be assumed that developing juveniles will find abundant prey resources during the summer and early autumn. Very few nemertines other than A. lactifloreus reproduce during the autumn (Friedrich, 


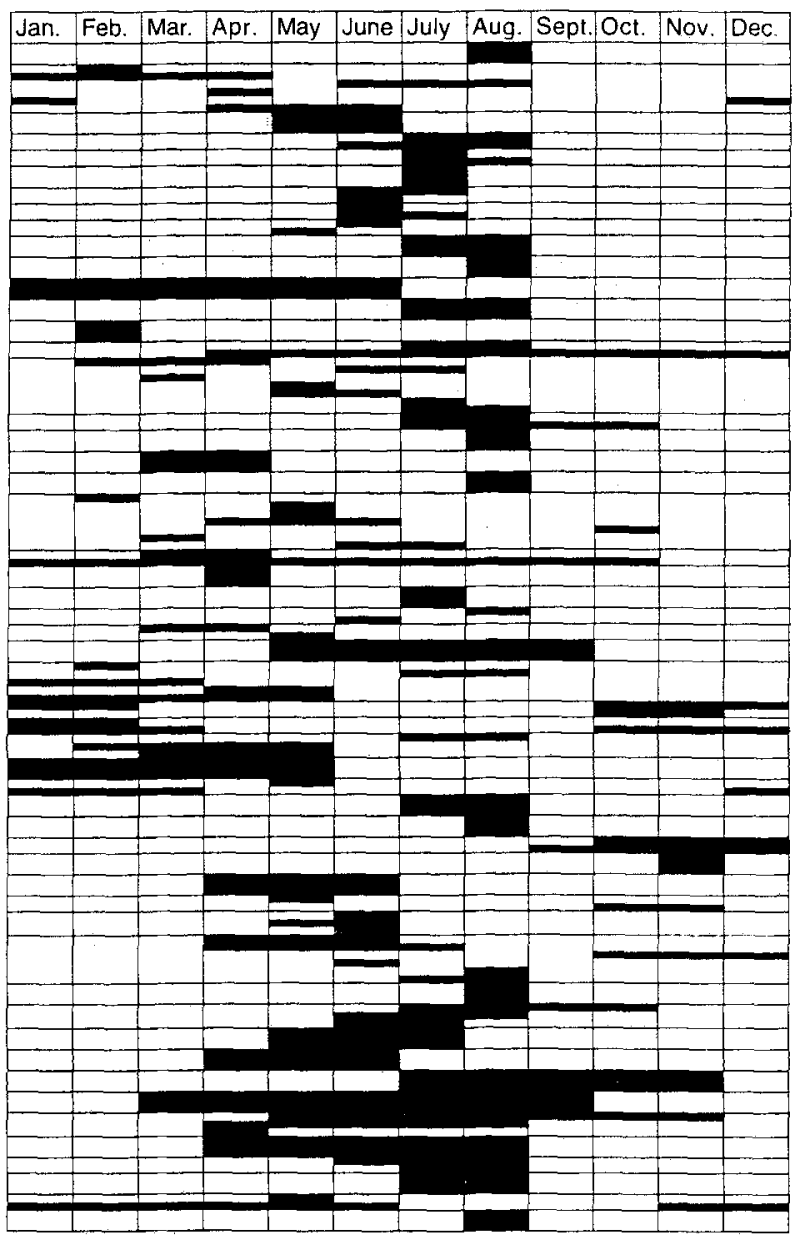

Fig. 8. Reproductive periods of 53 nemertine species from the temperate regions of the northern hemisphere. Horizontal lines separate the different species from each other. Information from various geographical areas or different authors may be given for particular species (see also Fig. 1). Where several reports are available for one species, the thickness of the horizontal columns is decreased

1979). No unifying character can be identified among these different groups of nemertines which reproduce in autumn.

During the reproductive period and following it, high numbers of A. lactifloreus could be observed at the sediment surface during nocturnal low tides (Thiel, 1992; Thiel et al., 1995). Throughout our observations and sample-collecting trips we found no indication of how $A$. lactifloreus reproduction might function. Some authors mention that A. lactifloreus deposits fertilized eggs in a cocoon-like mass on the bottom where they undergo direct development (Thorson, 1950, 1957), whereas other authors report that the gametes are freely shed into the water column (Bierne, 1983). Intensive field observations 
during night-time low tides in November are a promising project that may shed more light on how reproduction functions in A. lactifloreus.

\section{Life-history of Amphiporus lactifloreus}

The hoplonemertine Amphiporus lactifloreus is a very common intertidal nemertine along European coasts (Gibson, 1982). It feeds preferentially on amphipods of the genus Gammarus (Jennings \& Gibson, 1969; McDermott \& Roe, 1985). A. lactifloreus can be found in aggregations comprising several intermingled individuals within mussel clumps. Densities may be as high as 250 individuals $/ \mathrm{m}^{2}$ within these micro-habitats (Thiel \& Reise, 1993). The average food requirement of an adult individual A. lactifloreus was estimated from laboratory experiments to be about 0.15 amphipods / day (Thiel, 1992), a value which corresponds with values provided by McDermott $(1984$, 1993) for another hoplonemertine feeding on amphipods of a size similar to those preyed upon by A. lactifloreus.

The nemertine $A$. lactifloreus has the capacity to reproduce several times in subsequent reproductive periods, as can be concluded from our data. To our knowledge the present study is the first to show that a relatively small nemertine species is iteroparous. We conclude that in the field $A$. lactifloreus can reach an age of 2 years, because some individuals of the cohort that reproduced in November 1992 persisted in the field until July 1993 (see Figs 5 and 6).

The explanations for $A$. lactifloreus reproducing in autumn remain speculative. Gammarid amphipods in the Nord-Sylter Wattenmeer and along the northern European coasts reach their highest densities in spring and autumn (personal obs.). The reproductive period of $A$. lactifloreus immediately follows the period when gammarids reached peak numbers in autumn. This leads to the assumption that food availability may be a factor influencing the timing of reproduction in A. lactifloreus.

An alternative hypothesis would be the lack of potential predators of $A$. lactifloreus in its micro-habitat during autumn and winter months. A. lactifloreus preferentially inhabits mussel clumps on tidal flats and lives in large numbers under small rocks on rocky shores. The nemertine shares this habitat with many other invertebrates. Despite the widespread notion that nemertines have few or no enemies, shore crabs prey upon small nemertines (Gibson, pers. comm.; Thiel, 1992). Juvenile shore crabs (Carcinus maenas), which inhabit mussel clumps in large numbers, leave this habitat during the late fall (Thiel \& Dernedde, 1994). Thus, during the winter, small juveniles of $A$. lactifloreus would have a relatively predator-free habitat in mussel clumps.

\section{Biometrics of Amphiporus lactifloreus}

Measurements of length proved to be a relatively useful tool for investigating the population biology of the nemertine A. lactifloreus. Despite the fact that the size and shape of nemertines are highly variable (Gibson, 1972, 1982; Riser, 1974), their length is a good and consistent measure of their condition under both the 'relaxed' and anaesthetized condition, which is also true for the heteronemertine Lineus viridis (Thiel, unpubl. data). In the nemertine Nipponemertes pulcher, body length is a consistent measure for the number of eyes (Berg, 1972), and Heine et al. (1991) report the body length of 
Parborlasia corrugatus to be correlated with wet weight. The study of Roe (1976) shows that length measurements of 'relaxed' nemertines are a good tool for tracking annual cohorts over various time periods. Gibson (1983) and Roe (1976) demonstrated that 'body bulk' (length ' maximum width) is a good measure for wet weight. Figure 5 shows that with the help of the length measurements of 'relaxed' individuals, cohorts from different years can also be followed in the nemertine A. lactifloreus. As length measurements of anaesthetized individuals do not seem to be as consistent over time as those of 'relaxed' nemertines, we propose the latter measure for future studies on their population biology.

\section{Future studies on the population biology of intertidal nemertines}

Ready access and the relatively high abundances of nemertines found on the tidal flats invite studies on the population biology of intertidal species. Regular length measurements of nemertines promise to provide important information on the growth and survival of annual cohorts of nemertines. Furthermore, they will reveal whether the nemertine under investigation is an annual species. Optical examinations of living specimens often allow a determination to be made whether individuals have mature gonads, and when combined with data from length measurements, these data can indicate whether it is an iteroparous or semelparous nemertine, and whether all members of the population produce gametes.

The most difficult problem in future studies on the population biology of intertidal nemertines is to determine the recruitment process and the factors influencing its success. Future studies should first focus on those species that produce cocoons, as in these species the small juveniles hatch directly from the cocoon, e.g. in Lineus viridis (Bartolomaeus, 1984). Not surprisingly, $L$. viridis is one of the very few nemertines for which the juvenile habitat and development are known, but no data on juvenile growth and mortality are available at present (Cantell, 1989). Prime factors to be investigated with respect to the recruitment success of nemertines should be the food of small juveniles, their susceptibility to potential predators, and the reproductive potential of the adult population.

Our study shows that important life-history data of intertidal nemertines can be relatively easily obtained without time-consuming histological investigations. These data provide the basic information necessary for a better understanding of interannual variations in nemertine abundance and may subsequently help to understand the fluctuations in the abundance of their prey species.

Acknowledgements. We thank particularly R. Gibson who introduced us to the histological techniques used in this study, invited one of us to work for 2 months in his lab, and was always a source of important information. We thank K. Eckelbarger for allowing us to use the histology lab at the Darling Marine Center. Very special thanks go to S. Sampson for never losing patience when we bothered him with questions for help, material and technical advice. R. Gibson, K. Reise, P. Roe and $\mathrm{S}$. Sampson commented on the manuscript. We are grateful to K. Reise and S. Lorenzen who gave initial advice and helped us to locate financial resources. Financial support was provided by the Federal Ministry for Research and Technology, by travel funds from the University of Kiel and the 'Universitätsgesellschaft Kiel', and a fellowship grant by the Ministry of Education of SchleswigHolstein. 


\section{LITERATURE CITED}

Albrecht, A., 1991. Einfluß der Braunalge Fucus vesiculosus auf die Lebensgemeinschaft von Miesmuschelbänken im Wattenmeer. Dipl.Arb., Univ. Göttingen, 79pp.

Albrecht, A. \& Reise, K., 1994. Effects of Fucus vesiculosus covering intertidal mussel beds in the Wadden Sea. - Helgoländer Meeresunters. 48, 243-256.

Ambrose, W. G., 1991. Are infaunal predators important in structuring marine soft-bottom communities? - Am. Zool. 31, 849-860.

Bartolomaeus, T., 1984. Zur Fortpflanzungsbiologie von Lineus viridis (Nemertini). - Helgoländer Meeresunters. 38, 185-188.

Berg, G., 1972. Studies on Nipponemertes Friedrich, 1968 (Nemertini, Hoplonemertini). - Zool. Scr. $1,211-225$.

Bierne, J., 1983. Nemertina. In: Reproductive biology of invertebrates. Ed. by K. G. Adiyodi \& R. G. Adiyodi. Wiley, New York, 1, 147-167.

Bierne, J. \& Rué, G., 1979. Endocrine control of reproduction in two rhynchocoelan worms. - Int. J. Invert. Reprod. 1, 109-120.

Bürger, O., 1897-1907. Nemertini. - Bronn's Kl. Ordn. Tierreichs 4, Abt. 2, Suppl., 1-542.

Cantell, C.-E., 1989. Nemertina. In: Reproductive biology of invertebrates. Ed. by K. G. Adiyodi \& R. G. Adiyodi. Wiley, New York, 4A, 147-165.

Coe, W. R., 1943. Biology of the nemerteans of the Atlantic coast of North America. - Trans. Conn. Acad. Arts Sci. 35, 129-328.

Franzen, A., 1956. On spermiogenesis, morphology of the spermatozoon, and biology of fertilization among invertebrates. - Zool. Bidr. Upps. 31, 355-482.

Franzen, $\AA$., 1983. Nemertina. In: Reproductive biology of invertebrates. Ed. by K. G. Adiyodi \& R. G. Adiyodi. Wiley, New York, 2, 159-170.

Friedrich, H., 1979. Nemertini. In: Morphogenese der Tiere. Hrsg. von F. Seidel. Fischer, Stuttgart, 3 , $1-136$.

Gibson, R., 1972. Nemerteans. Hutchinson, London, 224 pp.

Gibson, R., 1982. British nemerteans. Cambridge Univ. Press, Cambridge, 212 pp..

Gibson, R., 1983. Antarctic nemerteans: The anatomy, distribution, and biology of Parbolasia corrugatus (McIntosh, 1876) (Heteronemertea, Lineidae). - Antarct. Res. Ser. 39 (4), 289-316.

Gibson, R. \& Young, J. O., 1976. Ecological observations on a population of the freshwater hoplonemertean Prostoma jenningsi Gibson and Young 1971. - Arch. Hydrobiol. 78, 42-50.

Heine, J. N., McClintock, J. B., Slattery, M. \& Weston, J., 1991. Energetic composition, biomass, and chemical defense in the common antarctic nemertean Parborlasia corrugatus McIntosh. - J. exp. mar. Biol. Ecol. 153, 15-25

Jennings, J. B. \& Gibson, R., 1969. Observations on the nutrition of seven species of rhynchocoelan worms. - Biol. Bull. mar. biol. Lab., Woods Hole 136, 405-433.

McDermott, J. J., 1984. The feeding biology of Nipponemertes pulcher (Johnston) (Hoplonemertea), with some ecological implications, - Ophelia 23, 1-21.

McDermott, J. J., 1993. Nemertea inhabiting the Haploops (Amphipoda) community of the northern Øresund with special reference to the biology of Nipponemertes pulcher (Hoplonemertea). Hydrobiologia 266, 15-28

McDermott, J. J. \& Roe, P., 1985. Food, feeding behavior and feeding ecology of nemerteans. - Am. Zool. 25, 113-125.

McIntosh, W. C., 1873-74. A monograph of the British annelids. Part 1. The nemerteans. Ray Soc., London, $214 \mathrm{pp}$.

Nordhausen, W., 1988. Impact of the nemertean Lineus viridis on its polychaete prey on an intertidal sandflat. - Hydrobiologia 156, 39-46.

Reise, K., 1985. Tidal flat ecology. Springer, Berlin, $191 \mathrm{pp}$.

Reise, K., Herre, E. \& Sturm, M., 1989. Historical changes in the benthos of the Wadden Sea around the island of Sylt in the North Sea. - Helgoländer Meeresunters. 43, 417-433.

Riser, N. W., 1974. Nemertinea. In: Reproduction of marine invertebrates. Ed. by A. C. Giese \& J. S. Pearse. Acad. Press, New York, 359-389.

Roe, P., 1970. The nutrition of Paranemertes peregrina (Rhynchocoela: Hoplonemertea). I. Studies on food and feeding behavior. - Biol Bull. mar. biol. Lab., Woods Hole 139, 80-91. 
Roe, P., 1976. Life history and predator-prey interactions of the nemertean Paranemertes peregrina. - Biol. Bull. marl. biol. Lab., Woods Hole 150, 80-106.

Roe, P., 1993. Aspects of the biology of Pantinonemertes californiensis, a high intertidal nemertean. Hydrobiologia 266, 29-44.

Rowell, T. W. \& Woo, P., 1990. Predation by the nemertean worm, Cerebratulus lacteus Verrill, on the soft-shell clam, Mya arenaria Linnaeus, 1758, and its apparent role in the destruction of a clam flat. - J. Shellfish Res. 9, 291-297.

Thiel, M., 1992. Zur Ökologie von Nemertinen im Wattenmeer. Dipl.Arb., Univ, Kiel, 69 pp.

Thiel, M. \& Reise, K., 1993. Interaction of nemertines and their prey on tidal flats. - Neth. J. Sea Res. 31, 163-172.

Thiel, M. \& Dernedde, T., 1994. Recruitment of shore crabs (Carcinus maenas) on tidal flats - mussel clumps as an important refuge for juveniles. - Helgoländer Meeresunters. 48, 321-332.

Thiel, M., Nordhausen, W. \& Reise, K., 1995. Nocturnal surface activity of endobenthic nemertines. In: Biology and ecology of shallow coastal waters. Ed. by A. Eleftheriou, A. D. Ansell \& C. J. Smith. Olsen \& Olsen, Fredensborg, 283-293.

Thorson, G., 1950. Reproductive and larval ecology of marine bottom invertebrates. - Biol. Rev. 25, $1-45$.

Thorson, G., 1957. Reproduction and larval development of Danish marine bottom invertebrates, with special reference to the planktonic larvae in the Sound (Øresund). Reitzel, København, $523 \mathrm{pp}$. 